\title{
Protective effects of black tea extract against oxidative DNA damage in human lymphocytes
}

\author{
MIRIAM JEŽOVIČOVÁ ${ }^{1}$, KATARÍNA KOŇARIKOVÁ ${ }^{1}$, ZDEŇKA ĎURAČKOVÁ ${ }^{1}$, \\ JÁN KERESTEŠ ${ }^{2}$, GABRIEL KRÁLIK ${ }^{3}$ and INGRID ŽITŇANOVÁ ${ }^{1}$ \\ ${ }^{1}$ Institute of Medical Chemistry, Biochemistry and Clinical Biochemistry, Faculty of Medicine, \\ Comenius University, Bratislava $81372 ;{ }^{2}$ Molecule of Life, Ltd., Lichnerova, Senec 903 01; \\ ${ }^{3}$ Radiotherapy Department of St. Elisabeth Cancer Institute, Bratislava 813 72, Slovakia
}

Received February 16, 2015; Accepted November 10, 2015

DOI: $10.3892 / \mathrm{mmr} .2015 .4747$

\begin{abstract}
The aim of the present study was to examine the genoprotective and radioprotective effects of black tea extract (BTE) against the induction of single strand DNA breaks in human lymphocytes subjected to hydrogen peroxide $\left(\mathrm{H}_{2} \mathrm{O}_{2}\right)$ or gamma-rays (2 Gy dose). Lymphocytes were incubated with or without different concentrations of BTE $(0.005-500 \mu \mathrm{g} / \mathrm{ml})$ for $30 \mathrm{~min}$, followed by treatment with or without $\mathrm{H}_{2} \mathrm{O}_{2}(0.088 \mu \mathrm{mol} / \mathrm{l})$ for $5 \mathrm{~min}$. To examine the radioprotective effect of BTE, the lymphocytes were incubated with or without BTE for 30 and $60 \mathrm{~min}$ prior to and following in vitro irradiation. Oxidative damage to DNA was monitored using a comet assay. BTE at lower concentrations prevented $\mathrm{H}_{2} \mathrm{O}_{2}$-induced DNA damage. An increase in BTE concentrations resulted in increased formation of single strand DNA breaks. BTE also exerted significant protective effects against gamma radiation-induced total DNA damage in healthy lymphocytes during their 30 or $60 \mathrm{~min}$ incubation with BTE prior to or following irradiation. Therefore, the protective effect of BTE against irradiation was time-dependent. The results contribute to the research on potential beneficial effects of natural compounds, such as BTE, in cancer and its protective effects of normal tissue during radiation therapy.
\end{abstract}

\section{Introduction}

Radiation therapy is an important treatment for several diseases, including cancer, in humans (1). The primary obstacle in radiation therapy is the induction of normal tissue injury, resulting in cell death and acquired radioresistance in

Correspondence to: Dr Ingrid Žitňanová, Institute of Medical Chemistry, Biochemistry and Clinical Biochemistry, Faculty of Medicine, Comenius University, Sasinkova 2, Bratislava 81372 , Slovakia

E-mail: ingrid.zitnanova@fmed.uniba.sk

Key words: black tea extract, oxidative DNA damage, gamma radiation, hydrogen peroxide, human lymphocytes cancer cells during radiotherapy (2). Hematological tissue, particularly lymphocytes, is one of the tissues, which is particularly sensitive to radiation (3). Ionizing radiation generates free radicals and reactive oxygen species (ROS). ROS can oxidatively damage biological macromolecules, including lipids, DNA and proteins and, as a consequence, cellular damage occurs resulting in genomic instability and leading to mutagenesis, carcinogenesis and cell death (4). The direct or indirect (free radical-induced DNA damage) interactions of gamma-rays with DNA can cause various lesions, including oxidized purines or pyrimidines, apurinic or apyrimidinic sites, as well as modifications of sugars (5-7). DNA can be attacked by endogenous and exogenous ROS, and by xenobiotics, resulting in DNA damage (8). Hydrogen peroxide $\left(\mathrm{H}_{2} \mathrm{O}_{2}\right)$ is a reactive compound, which can generate hydroxyl radicals $(\mathrm{OH})$ at elevated concentrations via the Fenton reaction. $\mathrm{OH}$ has a high affinity to DNA causing the strand breaks, and this process can result in DNA instability, mutagenesis and ultimately carcinogenesis $(9,10)$.

The use of natural products with antioxidant activity has gained momentum as possible radioprotectors in previous years due to their advantages, including lower toxicity and reduced cost (11-13). Black tea is rich in polyphenolic compounds, particularly theaflavins, and polyphenolic compounds considerably mitigate the effects of ionizing irradiation at the molecular, cellular and/or tissue level (14-16). However, there remains a lack of information regarding protective effects of black tea extract (BTE) against $\mathrm{H}_{2} \mathrm{O}_{2}$-induced DNA damage in healthy human lymphocytes.

The aim of the present study was to evaluate the total antioxidant capacity of BTE, and to examine its genoprotective and radioprotective effects against the oxidative DNA damage induced by $\mathrm{H}_{2} \mathrm{O}_{2}$ and ${ }^{60} \mathrm{Co}$ gamma-rays in healthy human lymphocytes. For this investigation, a comet assay was used to detect single strand DNA breaks, and a formamidopyrimidine glycosylase (Fpg)-assisted comet assay was used to detect total DNA damage (single strand DNA breaks and oxidized purines). Fpg creates strand breaks at oxidation-induced DNA lesions, increasing the specificity and sensitivity of the comet assay (17). The present study focused on determining possible protective effects of BTE against radiation injury during cancer therapy. 


\section{Materials and methods}

Chemicals and reagents. All solutions and chemicals used in the present study were purchased from Sigma-Aldrich (Irvine, $\mathrm{UK})$.

BTE preparation. The BTE was provided by Dr Ján Keresteš (Molecule of Life, Ltd., Senec, Slovakia). The BTE consisted of a powder $(0.1 \mathrm{~g})$, which was dissolved in $10 \mathrm{ml}$ distilled water $\left(45-48^{\circ} \mathrm{C}\right)$ and mixed for $24 \mathrm{~h}$ using a magnetic stirrer (IKA, Staufen, Germany). The extract was then filtered through filter paper, and stock solution was prepared at a final concentration of $2 \mathrm{mmol} / \mathrm{l}$, which was stored at $4^{\circ} \mathrm{C}$. The BTE was diluted in the concentration range of $0.01-1 \mathrm{mmol} / 1$ appropriately with distilled water prior to treatment. The content of the active flavonoids was determined by pyrolysis of the product following determination of the individual compounds of the product by spectrophotometry and absorption chromatography (18). The content of active flavonoids in the BTE extract was at least $96 \%$, containing catechins (60-75\%), leukoantocyanidins (25-40\%), cyanidins and general flavone derivatives of diols. The complexes of the flavonoids were in mono and oligomeric forms.

Cell preparation. Blood samples were collected from healthy volunteers $(n=9)$ from the antecubital vein. The volunteers included nine females (30-40 years old). Written informed consent was obtained from all volunteers. The study was approved by the ethics committee of the Faculty of Medicine, Comenius University and the University Hospital (Bratislava, Slovakia). Human lymphocytes were isolated from the fresh blood $(10 \mathrm{ml})$ with the anticoagulant EDTA, by adding phosphate-buffered saline (PBS; $10 \mathrm{ml}$ ), and then underlaying it with Histopaque $(10 \mathrm{ml})$ prior to centrifugation at $350 \mathrm{x}$ g for $15 \mathrm{~min}$ at $4^{\circ} \mathrm{C}$. The lymphocytes were separated as a layer at the top of the Histopaque, removed and resuspended in PBS (10 ml). Following centrifugation at $290 \mathrm{x}$ g for $20 \mathrm{~min}$ at $4^{\circ} \mathrm{C}$, the supernatant was removed. PBS was added to the sediment of lymphocytes and a suspension containing $2.5 \times 10^{5}$ cells/gel was used for BTE treatment.

Treatment with $\mathrm{H}_{2} \mathrm{O}_{2}$. The lymphocytes $\left(2.5 \times 10^{5}\right.$ cells/gel $)$ were incubated with or without different concentrations of BTE $(0.005,0.05,0.5,5,25,50$ and $500 \mu \mathrm{g} / \mathrm{ml})$ for $30 \mathrm{~min}$ in the dark at room temperature. The samples were then centrifuged at $350 \mathrm{x} \mathrm{g}$ for $7 \mathrm{~min}$ at $4^{\circ} \mathrm{C}$, washed with PBS and centrifuged again. The cells $\left(2.5 \times 10^{5}\right.$ cells/gel $)$ were treated with or without $\mathrm{H}_{2} \mathrm{O}_{2}(0.088 \mu \mathrm{mol} / \mathrm{l}$ for $5 \mathrm{~min}$ on ice $)$ in the dark. Control samples were treated with PBS alone, without hydrogen peroxide.

Treatment with ${ }^{60}$ Co gamma-rays. The lymphocytes were divided into two groups: Group A comprised BTE (0.005-500 $\mu \mathrm{g} / \mathrm{ml})$-pretreated lymphocytes subjected to $2 \mathrm{~Gy}$ gamma-irradiation. Group B comprised 2 Gy gamma-irradiated lymphocytes, which were post-treated with BTE (0.005-500 $\mu \mathrm{g} / \mathrm{ml})$.

The lymphocytes with or without BTE pretreatment were isolated and embedded in a Petri dish, covered and irradiated for 2.36 min. Cobalt 60 (Co-60; Theratron Elite 100, Nordion Inc., Kanata, ON, Canada) radiation delivery was performed in the Radiotherapy Department of St. Elisabeth Cancer Institute, (Bratislava, Slovakia). Radiation was administered at a dose of 2 Gy. The samples remained incubated with BTE at room temperature for 30 or $60 \mathrm{~min}$ immediately following or prior to irradiation.

Comet assay. DNA strand breaks and oxidative DNA damage were measured using an alkaline comet assay (19). The cell suspension was added to microscope slides precoated with $1 \%$ normal melting agarose. The slides were immersed in cold lysing solution (containing $2.5 \mathrm{~mol} / 1 \mathrm{NaCl}, 100 \mathrm{mmol} / \mathrm{l}$ EDTA and $10 \mathrm{mmol} / \mathrm{l}$ of $1 \%$ Triton $\mathrm{X}-100, \mathrm{pH} \mathrm{10)}$ for at least $1 \mathrm{~h}$ at $4^{\circ} \mathrm{C}$. For the enzyme treatment, the slides were removed from the lysis buffer and incubated with enzyme reaction buffer $(40 \mathrm{mmol} / 1 \mathrm{Hepes}, 0.1 \mathrm{~mol} / \mathrm{l} \mathrm{KCl}, 0.5 \mathrm{mmol} / 1$ EDTA and $200 \mathrm{mg} / \mathrm{ml} \mathrm{BSA,} \mathrm{pH} \mathrm{8;} \mathrm{Sigma-Aldrich)} \mathrm{for}$ $10 \mathrm{~min}$ at $4^{\circ} \mathrm{C}$. Thereafter, $50 \mu \mathrm{l}$ formamidopyrimidine glycosylase (Fpg; 1:3,000) was added to the slide and the slides were incubated at $37^{\circ} \mathrm{C}$ for $30 \mathrm{~min}$. The enzyme treatment control slide was incubated with enzyme reaction buffer only. Following enzyme treatment, the cover slips were removed. The microscope slides were then placed in an electrophoresis tank, and the DNA was allowed to unwind for $40 \mathrm{~min}$ in freshly prepared alkaline electrophoresis buffer (containing $0.2 \mathrm{~mol} / 1 \mathrm{Na}_{2}$ EDTA and $5 \mathrm{~mol} / \mathrm{l} \mathrm{NaOH}$; pH 13). Electrophoresis was conducted at $4^{\circ} \mathrm{C}$ for $30 \mathrm{~min}$ at $25 \mathrm{~V}$ and $300 \mathrm{~mA}$. The slides were washed twice at $4^{\circ} \mathrm{C}(10 \mathrm{~min}$ each $)$ with neutralising buffer $(0.4 \mathrm{~mol} / 1$ Tris- $\mathrm{HCl}, \mathrm{pH} 7.5)$. All chemicals were obtained from Sigma-Aldrich. Comets were visualized using fluorescence microscopy Olympus BX-41 (Olympus, Tokyo, Japan) following staining with 4',6-diamidine-2-phenylindole dihydrochloride (Merck, Darmstadt, Germany). The intensity of the comet tail relative to the head reflects the number of DNA breaks and is scored manually. A total of 100 cells from each of two replicate slides were analyzed for each BTE concentration and were classified into five classes, according to the relative intensity of fluorescence in the tail. These classes were scored between 0 and 4 , with 0 indicating no damage and 4 exhibiting maximal damage. Therefore, the total score for the 100 comets had a potential range of between 0 (all undamaged) and 400 (all maximally damaged).

The total damage (TD) of the DNA was evaluated according to the following formula:

$$
\mathrm{TD}=\sum_{\mathrm{i}=0}^{4} \mathrm{i} . \mathrm{N}_{\mathrm{i}}
$$

Where i, represents the class of damage and $\mathrm{N}$ represents the number of cells in the class. The percentage of DNA damage was calculated according to the following formula: $\%$ DNA damage $=(T D / 400) \times 100$.

Total antioxidant capacity of BTE. The total antioxidant status of the BTE was determined using a Trolox Equivalent Antioxidant Capacity (TEAC) method (20). Briefly, ABTS solution (containing $14 \mathrm{mmol} / \mathrm{l}$ ABTS and $4.9 \mathrm{mmol} / \mathrm{l}$ $\mathrm{K}_{2} \mathrm{~S}_{2} \mathrm{O}_{8}$ ) (Sigma-Aldrich) was diluted with deionized water until an absorbancy of $0.7 \pm 0.02$ at $734 \mathrm{~nm}$ was reached. To $1,980 \mu \mathrm{l}$ of ABTS working solution $10 \mu \mathrm{l}$ BTE sample was 


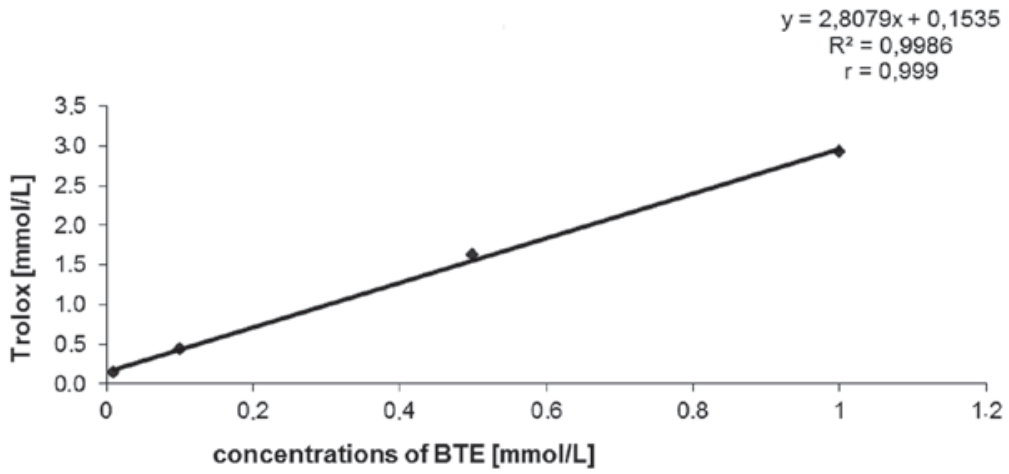

Figure 1. Total antioxidant status of BTE at concentrations of 1, 0.5, 0.1 and $0.01 \mathrm{mmol} / \mathrm{l}$ in vitro. BTE, black tea extract.

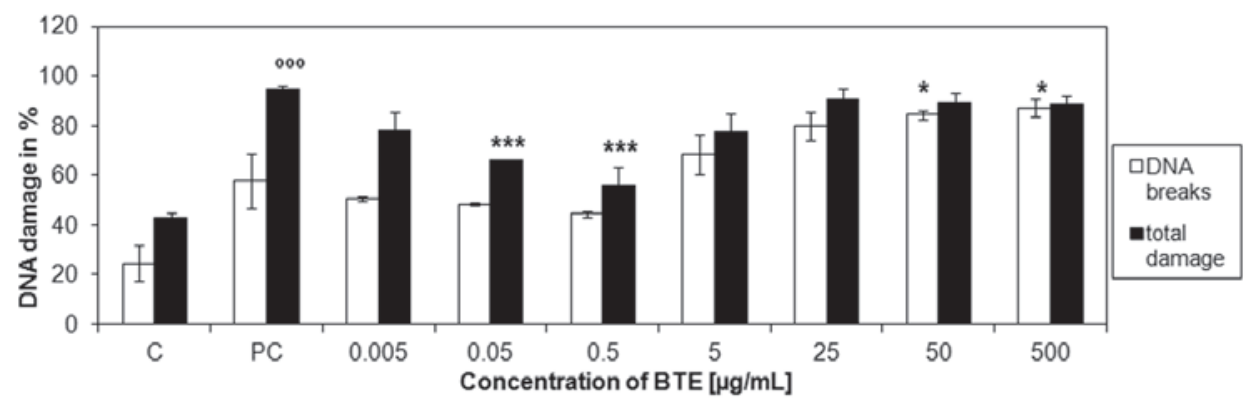

Figure 2. Effect of BTE on single strand DNA breaks and total DNA damage (oxidized purine bases and DNA strand breaks) in human lymphocytes. DNA damage was assessed as DNA strand breaks in cells treated with BTE (0.005-500 $\mu \mathrm{g} / \mathrm{ml})$ without Fpg enzyme, and total damage (total DNA damage) in cells treated with BTE $(0.005-500 \mu \mathrm{g} / \mathrm{ml})$ and Fpg enzyme. Human lymphocytes were preincubated with BTE $(0.005-500 \mu \mathrm{g} / \mathrm{ml})$ for $30 \mathrm{~min}$, prior to exposure to $\mathrm{H}_{2} \mathrm{O}_{2}$ for 5 min. Results are presented as the mean \pm standard error of the mean $(\mathrm{n}=7)$. ${ }^{*} \mathrm{P}<0.05$ and ${ }^{* * * *} \mathrm{P}<0.001$, compared with the $\mathrm{PC}$ group. ${ }^{\circ 00} \mathrm{P}<0.0001$, compared with the $\mathrm{C}$ group. C, control cells without exposure to $\mathrm{H}_{2} \mathrm{O}_{2}$ or BTE, $\mathrm{PC}$, positive control cells exposed to $\mathrm{H}_{2} \mathrm{O}_{2}$ without BTE. BTE, black tea extract; Fpg, formamidopyrimidine glycosylase.

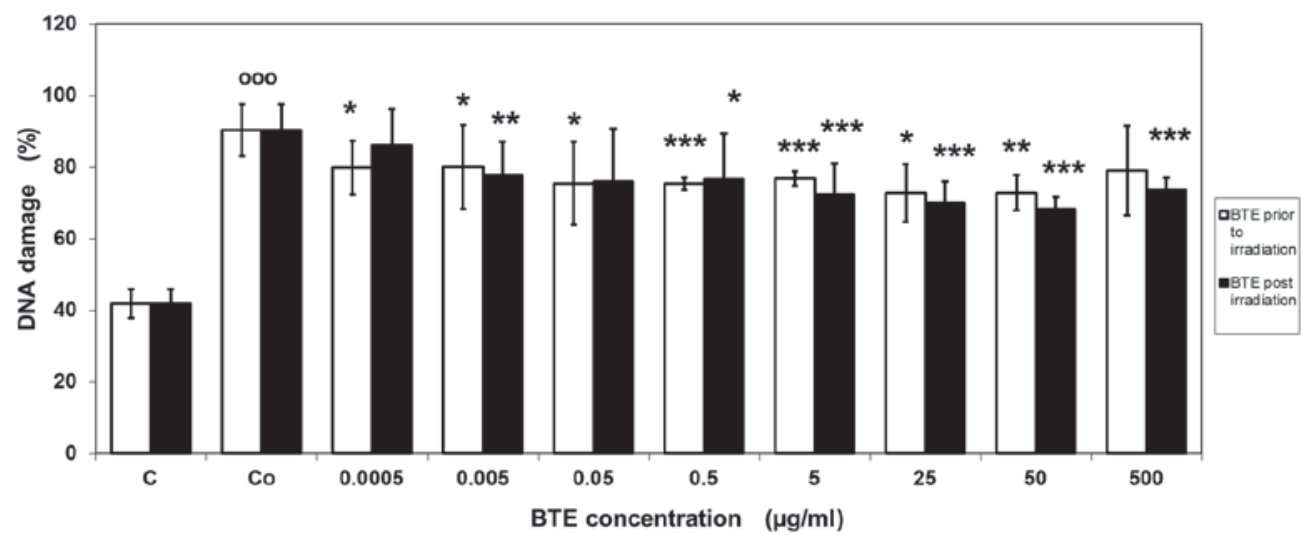

Figure 3. Single strand DNA breaks and total DNA damage (oxidized purine bases and DNA single strand breaks) induced by gamma irradiation in human lymphocytes during $30 \mathrm{~min}$ incubation with or without BTE prior to and following irradiation. White columns represent BTE incubation prior to lymphocyte irradiation; black columns represent BTE incubation post-irradiation. The cells were treated with BTE $(0.0005-500 \mu \mathrm{g} / \mathrm{ml})$ and incubated with formamidopyrimidine glycosylase enzyme. Results are presented as the mean \pm standard deviation $(\mathrm{n}=9)$. ${ }^{*} \mathrm{P}<0.05,{ }^{* * *} \mathrm{P}<0.01$ and ${ }^{* * * *} \mathrm{P}<0.001$, compared with the Co group. ${ }^{{ }^{\circ o} \mathrm{P}}<0.001$, compared with the $\mathrm{C}$ group. C, control cells without irradiation or BTE treatment. Co, positive control-cells exposed to 60Co gamma-rays (2 Gy) without BTE; BTE, black tea extract.

added and the absorbance (734 $\mathrm{nm}$ ) was recorded (UV-1700 PharmaSpec, Shimadzu Corporation, Tokyo, Japan) against deionized water at 0 and $10 \mathrm{~min}$. The antioxidant ability of the BTE was determined from the analytical curve with trolox standard (Sigma-Aldrich), a synthetic, hydrophilic form of vitamin E. Total antioxidant capacity was expressed as mmol trolox/l.
Statistical analysis. Results are expressed as the arithmetic mean \pm standard deviation of three separate experiments. Each experiment was performed with three parallels. Statistical evaluations were performed using a parametric unpaired t-test. $\mathrm{P}<0.05$ was considered to indicate a statistically significant difference. StatsDirectR v.2.3.7 (StatsDirect Ltd., Sale, UK) was used for the statistical analysis. 


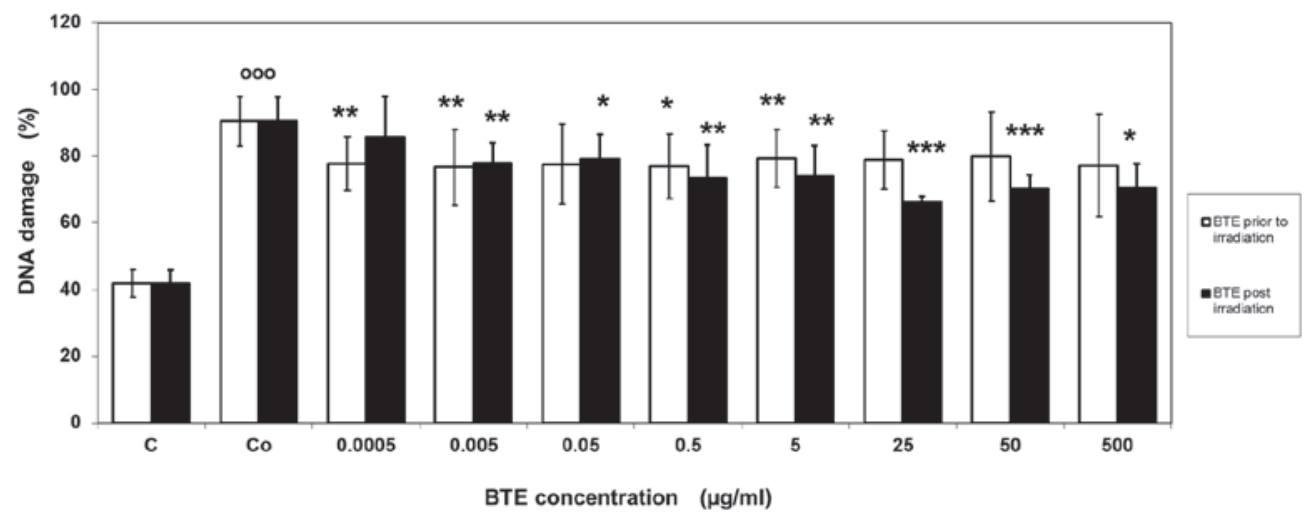

Figure 4. Total DNA damage (oxidized purine bases and DNA strand breaks) induced by gamma-irradiation in human lymphocytes during 60 min incubation with or without BTE prior to or following irradiation. White columns represent BTE incubation prior to lymphocyte irradiation; black columns represent BTE incubation post-irradiation. C, control cells without irradiation or BTE treatment, Co, positive control-cells exposed to ${ }^{60} \mathrm{Co} \gamma$-rays $(2$ Gy) without BTE. The cells were treated with BTE $(0.0005-500 \mu \mathrm{g} / \mathrm{ml})$ and incubated with formamidopyrimidine glycosylase enzyme. Results are presented as the mean \pm standard deviation ( $\mathrm{n}=9)$. ${ }^{*} \mathrm{P}<0.05$ and ${ }^{* *} \mathrm{P}<0.01$, compared with the Co group. ${ }^{\circ 0} \mathrm{P}<0.001$, compared with the C group. BTE, black tea extract.

\section{Results}

Total antioxidant status of the BTE. The total antioxidant status of the BTE was determined using the TEAC method, and was found to be concentration-dependent within the concentration range of 0.01 and $1 \mathrm{mmol} / 1$ (Fig. 1). A BTE concentration of $1 \mathrm{mmol} / \mathrm{l}$ exhibited the same antioxidant ability as a $2.9 \mathrm{mmol} / \mathrm{l}$ concentration of trolox, indicating that the antioxidant effects of BTE were almost three times more effective than those of trolox.

Effect of BTE on $\mathrm{H}_{2} \mathrm{O}_{2}$-induced DNA damage. The present study investigated the protective effect of BTE against $\mathrm{H}_{2} \mathrm{O}_{2}$-induced DNA damage, which was achieved through monitoring single strand DNA breaks and the total DNA damage (oxidized purine bases and DNA strand breaks) using a comet assay and Fpg-assisted comet assay. Fpg is an enzyme, which cleaves DNA at sites with oxidized purine nitrogen bases (21). The total DNA damage (black bars in Fig. 2) in the lymphocytes incubated with $\mathrm{H}_{2} \mathrm{O}_{2}$ (PC-positive control; $94.5 \pm 1.7 \%)$ was significantly higher $(\mathrm{P}<0.001)$, compared with that in the lymphocytes without $\mathrm{H}_{2} \mathrm{O}_{2}$ (C-control; 43.1 $2.0 \%$; Fig. 2). Treatment with the BTE extract reduced the total DNA damage in the human lymphocytes, with the maximum effect observed at a concentration of $0.5 \mu \mathrm{g} / \mathrm{ml}(\mathrm{P}<0.001)$. BTE at low concentrations proved antioxidant properties by its ability to protect DNA against oxidative damage to purines. At concentrations between 5 and $500 \mu \mathrm{g} / \mathrm{ml}$, the BTE had no significant protective effect against $\mathrm{H}_{2} \mathrm{O}_{2}$-induced total DNA damage.

The $\mathrm{H}_{2} \mathrm{O}_{2}$-induced single strand DNA breaks, which were determined in the absence of Fpg (white bars in Fig. 2) were not affected by BTE up to a concentration of $0.5 \mu \mathrm{g} / \mathrm{ml}$. However, higher concentrations of BTE, between 5 and $500 \mu \mathrm{g} / \mathrm{ml}$, induced the generation of single strand DNA breaks, thus contributing to the DNA damaging effect of $\mathrm{H}_{2} \mathrm{O}_{2}$.

Effect of BTE on ${ }^{60}$ Co gamma-ray induced DNA damage. The total DNA damage in the lymphocytes irradiated with 2 Gy ${ }^{60} \mathrm{Co}$ gamma-rays $(90.3 \% \pm 7.3)$ was significantly higher
$(\mathrm{P}<0.001)$, compared with that in the control lymphocytes without irradiation or BTE treatment $(41.8 \% \pm 4.2$; Fig. 3).

Incubation of the lymphocytes with BTE extract for $30 \mathrm{~min}$ prior to gamma-irradiation significantly reduced the total DNA damage $(\mathrm{P}<0.05)$ by $10.4 \%$ at the lowest concentration of BTE $(0.0005 \mu \mathrm{g} / \mathrm{ml}$; Fig. 3). The maximum reduction of DNA damage was observed at BTE concentrations of 0.5 and $5 \mu \mathrm{g} / \mathrm{ml}(\mathrm{P}<0.001)$. However, the highest concentration of BTE $(500 \mu \mathrm{g} / \mathrm{ml})$ had no protective effect on the lymphocytes against 2 Gy ${ }^{60} \mathrm{Co}$ gamma-ray-induced total DNA damage. When the BTE extract was incubated with the human lymphocytes 30 min following gamma-irradiation, the total DNA damage was reduced by $12.6 \%$ at a concentration of $0.005 \mu \mathrm{g} / \mathrm{ml} \mathrm{BTE \text {. }}$ The maximum effect against DNA damage was observed when the concentration of BTE was $25 \mu \mathrm{g} / \mathrm{ml}(22 \%$; $\mathrm{P}<0.001)$.

Lymphocytes from the healthy volunteers treated with BTE for 60 min prior to gamma radiation exhibited reduced levels of total DNA damage, which were $12.7 \%$ lower at the lowest BTE concentration $(0.0005 \mu \mathrm{g} / \mathrm{ml})$, compared with the control (Fig. 4). The levels of DNA damage did not change significantly within the BTE concentration range. The lymphocytes incubated with BTE for 60 min following gamma-irradiation exhibited the minimum level of DNA damage at a BTE concentration of $25 \mu \mathrm{g} / \mathrm{ml}(\mathrm{P}<0.001$; Fig. 4).

\section{Discussion}

The present study demonstrated that the BTE had significant protective effects against gamma-irradiation-induced total DNA damage (oxidized purine bases and DNA strand breaks) and $\mathrm{H}_{2} \mathrm{O}_{2}$-induced DNA damage in healthy lymphocytes. On examining gamma-irradiation-induced total DNA damage, BTE showed protective effects at all concentrations used in the present study, whereas in $\mathrm{H}_{2} \mathrm{O}_{2}$-induced DNA damage, BTE protected DNA only at lower BTE concentrations.

The mechanisms by which tea polyphenols may act remain to be fully elucidated. The present study hypothesized that the inhibition of promutagen activation, inactivation of mutagens and carcinogens, inhibition and scavenging of reactive molecules, modulation of DNA replication or repair, 
inhibition of promotion, and inhibition of the invasion and metastasis of tumor cells may be involved. As DNA is the major target of radiation-induced damage, the ability of BTE to prevent radiation-induced DNA damage was investigated in healthy lymphocytes in the present study. BTE exhibited an antioxidative capacity, which was three times higher than that of the trolox antioxidant, determined using a TEAC method in vitro. A previous study by Sun et al (22) found that black tea and its predominant polyphenols were effective in scavenging 1,1-diphenyl-2-picrylhydrazyl, 2,2'-azino-bis(3-ethylbenzothiazoline-6-sulphonic acid and $\mathrm{OH}$ free radicals in vitro in mice. DNA damage can be induced by ROS. $\mathrm{H}_{2} \mathrm{O}_{2}$ is a reactive compound that, at higher concentrations, can generate $\mathrm{OH}$ free radicals via the Fenton reaction (23). $\mathrm{OH}$ can attack DNA at the sugar residue of the DNA backbone, which leads to the generation of single strand breaks, double strand breaks, DNA protein cross-links and DNA instability, mutagenesis and ultimately carcinogenesis (24).

Several studies have demonstrated protective effects of epigallocatechin-3-gallate (EGCG), the predominant polyphenolic component of green tea, on the generation of DNA strand breaks in human lymphocytes (25-27). Therefore, the present study aimed to investigate the effects of BTE on DNA oxidative damage on human healthy lymphocytes, using a comet assay. The results obtained showed that pretreatment of human lymphocytes with BTE for 30 min prior to $\mathrm{H}_{2} \mathrm{O}_{2}$ treatment caused significant protection against total DNA damage at BTE concentrations of $0.05 \mu \mathrm{g} / \mathrm{ml}$ and $0.5 \mu \mathrm{g} / \mathrm{ml}(\mathrm{P}<0.001)$. By contrast, BTE concentrations $>5 \mu \mathrm{g} / \mathrm{ml}$ increased the generation of DNA single strand breaks. Similar results with EGCG have been reported in previous studies $(28,29)$. Johnson and Loo (28) treated human lymphocyte cells with EGCG, and found that treatment with a low concentration (10 $\mu \mathrm{mol} / \mathrm{l})$ decreased $\mathrm{H}_{2} \mathrm{O}_{2}$-induced strand breaks, whereas higher concentrations $(100 \mu \mathrm{mol} / \mathrm{l})$ increased DNA damage. Concentration is a factor, which may determine whether tea polyphenols act as antioxidants or pro-oxidants in vitro (30). These effects have been suggested to be due to spontaneous $\mathrm{H}_{2} \mathrm{O}_{2}$ generation by polyphenols in solution present at higher concentrations (31).

Theaflavins present in BTE have also been reported to produce $\mathrm{H}_{2} \mathrm{O}_{2}$ and induce apoptosis in several cell lines (32-34). Feng et al (35) confirmed that theaflavins remain potent antioxidants, which can protect normal rat liver cells against oxidative stress induced by $\mathrm{H}_{2} \mathrm{O}_{2}$ and tert-butyl hydroperoxide, and prevent cellular oxidative DNA damage. Wei et al (36) showed that extracts of green tea and black tea enhanced the scavenging of $\mathrm{H}_{2} \mathrm{O}_{2}$ and quenching of 8-hydroxy deoxyguanosine, suggesting the importance of EGCG in the antioxidant activities of tea extracts.

In the present study, the radioprotective effect of BTE was also investigated, to determine whether BTE treatment for 30 or $60 \mathrm{~min}$ prior to or following gamma-irradiation was more effective. BTE exerted the maximum protective effects against gamma-radiation-induced DNA damage in lymphocytes when incubated following irradiation at a dose of $25 \mu \mathrm{g} / \mathrm{ml}$ for $60 \mathrm{~min}$, and at a dose of $50 \mu \mathrm{g} / \mathrm{ml}$ for $30 \mathrm{~min}$. Treating lymphocytes with BTE for $30 \mathrm{~min}(25 \mu \mathrm{g} / \mathrm{ml})$ and $60 \mathrm{~min}(0.005 \mu \mathrm{g} / \mathrm{ml})$ prior to exposure to $2 \mathrm{~Gy}$ gamma-radia- tion resulted in a significant decrease in the protective effects, compared with incubation with BTE following irradiation. Higher concentrations of tea catechins present in the BTE may act synergistically with radiation due to their pro-oxidant activity (37)

Black tea accounts for $80 \%$ of the tea consumed worldwide, but its health advantages are less-well investigated compared with those of green tea. Black tea extract exhibited a three-times higher antioxidant capacity compared with trolox antioxidant, as determined by the TEAC method in vitro. The black tea extract obtained from Camellia sinensis exhibited genoprotective and radioprotective effects against oxidative DNA damage in human lymphocytes, possibly by decreasing oxidative stress due to its antioxidant nature. Protective effects of BTE are concentration dependent. Thus, BTE may be effective in reducing the risk of cancer development.

Ghosh et al (38) reported that efficient radioprotection is observed in normal lymphocytes at BTE concentrations as low as $5 \mu \mathrm{g} / \mathrm{ml}$, which may be assessed in the future as a natural antioxidant supplement during radiotherapy. The ability of black tea to inhibit free radical generation, scavenge free radicals and chelate transition metal ions depends on its antioxidative properties. Black tea, as well as individual theaflavins, can affect the activation of transcription factors, including nuclear factor $\kappa \mathrm{B}$ or activator protein-1 (39). AP-1 and NF- $\kappa \mathrm{B}$ are known to be important in tumor promoter-induced transformation, tumor promotion, tumor progression and metastasis. Tea polyphenols can act as inhibitors of tumor necrosis factor, and control the development and progression of tumors. Chung et al (40) demonstrated that all polyphenols of green and black teas exhibited strong inhibition of cell growth and AP-1 activity. The association between the antioxidant activity of tea polyphenols and the cancer-preventive effects of tea consumption requires further investigation, and additional experiments are required to examine the effectiveness of tea as a genoprotective agent and its underlying mechanism of action.

\section{Acknowledgements}

This study was financially supported by Molecule of Life, Ltd. (Senec, Slovakia) and by a grant from the Ministry of Education VEGA (grant no. 1/0752/13).

\section{References}

1. Mauch P, Constine L, Greenberger J, Knospe W, Sullivan J, Liesveld JL and Deeg HJ: Hematopoietic stem cell compartment: Acute and late effects of radiation therapy and chemotherapy. Int J Radiat Oncol Biol Phys 31: 1319-1339, 1995.

2. Kim W, Youn H, Seong KM, Yang HJ, Yun YJ, Kwon T, Kim YH, Lee JY, Jin YW and Youn B: PIM1-activated PRAS40 regulates radioresistance in non-small cell lung cancer cells through interplay with FOXO3a, 14-3-3 and protein phosphatases. Radiat Res 176: 539-552, 2011.

3. Gupta ML, Srivastava NN, Dutta S, Shukla SK, Dutta A, Verma $\mathrm{S}$ and Devi M: Blood biomarkers in metal scrap workers accidentally exposed to ionizing radiation: A case study. Hum Exp Toxicol 32: 1311-1322, 2013.

4. Srinivasan M, Devipriya N, Kalpana KB and Menon VP: Lycopene: An antioxidant and radioprotector against gamma-radiation-induced cellular damages in cultured human lymphocytes. Toxicology 262: 43-49, 2009. 
5. Imlay JA, Chin SM and Linn S: Toxic DNA damage by hydrogen peroxide through the Fenton reaction in vivo and in vitro. Science 240: 640-642, 1988.

6. Halliwell B and Gutteridge JM: Biologically relevant metal ion-dependent hydroxyl radical generation. An update. FEBS Lett 30: 108-112, 1992.

7. Josephson RA, Silverman HS, Lakatta EG, Stern MD and Zweier JL: Study of the mechanisms of hydrogen peroxide and hydroxyl free radical induced cellular injury and calcium overload in cardiac myocytes. J Biol Chem 266: 2354-2361, 1991.

8. Halliwell B and Gutteridge JMC (eds): Free Radicals in Biology and Medicine, 4th edition. Clarendon Press, Oxford, 2006.

9. Duthie SJ, Collins AR, Duthie GG and Dobson VL: Quercetin and myricetin protect against hydrogen peroxide-induced DNA damage (strand breaks and oxidized pyrimidines) in human lymphocytes. Mutat Res 393: 223-231, 1997.

10. Min K and Ebeler SE: Quercetin inhibits hydrogen peroxide-induced DNA damage and enhances DNA repair in Caco-2 cells. Food Chem Toxicol 47: 2716-2722, 2009.

11. Soobrattee MA, Bahorun T and Aruoma OI: Chemopreventive actions of polyphenolic compounds in cancer. Biofactors 27: 19-35, 2006.

12. Koláček M, Muchová J, Vranková S, Jendeková L, Pecháňová $\mathrm{O}$, Uličná $\mathrm{O}$, Watala $\mathrm{C}$ and Duračková Z: Effect of natural polyphenols, pycnogenol ${ }^{\circledR}$ on superoxide dismutase and nitric oxide synthase in diabetic rats. Prague Med Rep 111: 279-288, 2010.

13. Chan EWC, Soh EY, Tie PP and Law YP: Antioxidant and antibacterial properties of green, black and herbal teas of camellia sinensis. Pharmacognosy Res 3: 266-272, 2011.

14. Weiss JF and Landauer MR: Protection against ionizing radiation by antioxidant nutrients and phytochemicals. Toxicology 189: 1-20, 2003.

15. Weiss JF and Landauer MR: History and development of radiation-protective agents. Int J Radiat Biol 85: 539-573, 2009.

16. Hosseinimehr SJ: Trends in the development of radioprotective agents. Drug Discov Today 12: 794-805, 2007.

17. Collins AR and Dusinská M: Oxidation of cellular DNA measured with the comet assay. Methods Mol Biol 186: 147-159, 2002.

18. Fujihara T, Nakagawa-Izumi A, Ozawa $T$ and Numata $O$ High-molecular-weight polyphenols from oolong tea and black tea: purification, some properties, and role in increasing mitochondrial membrane potential. Biosci Biotechnol Biochem 71: 711-719, 2007.

19. Collins A, Dusinská M, Franklin M, Somorovská M, Petrovská H, Duthie S, Fillion L, Panayiotidis M, Raslová K and Vaughan N: Comet assay in human biomonitoring studies: Reliability, validation and applications. Environ Mol Mutagen 30: 139-146, 1997.

20. Re R, Pellegrini N, Proteggente A, Pannala A, Yang M and Rice-Evans C: Antioxidant activity applying an improved ABTS radical cation decolorization assay. Free Radic Biol Med 26: 1231-1237, 1999.

21. Langie SA, Azqueta A and Collins AR: The comet assay: past, present, and future. Front Genet 6: 266, 2015.

22. Sun S, Pan S, Ling C, Miao A, Pang S, Lai Z, Chen D and Zhao C: Free radical scavenging abilities in vitro and antioxidant activities in vivo of black tea and its main polyphenols. J Med Plant Res 6: 114-121, 2012.

23. Duračková Z: Some current insights into oxidative stress. Physiol Res 59: 459-469, 2010.

24. Evans MD, Dizdaroglu M and Cooke MS: Oxidative DNA damage and disease: Induction, repair and significance. Mutation Research 567: 1-61, 2004.
25. Yuquan L, Takeshita T and Morimoto K: Effects of (-)-epigallocatechin gallate (EGCG) on DNA strand breaks as evaluated by single-cell gel electrophoresis (SCG) in human lymphocytes. Environ Health Prev Med 5: 150-154, 2001.

26. Aydin S, Tokaç D, Başaran N and Başaran AA: Effect of epigallocatechin gallate on oxidative DNA damage in human lymphocytes. Turk J Pharm Sci 12: 19-28, 2015.

27. Kim W, Seong KM and Youn B: Phenylpropanoids in radioregulation: double edged sword. Exp Mol Med 43: 323-333, 2011.

28. Johnson MK and Loo G: Effects of epigallocatechin gallate and quercetin on oxidative damage to cellular DNA. Mutat Res 459: 211-218, 2000.

29. Tian B, Sun Z, Xu Z and Hua Y: Chemiluminescence analysis of the prooxidant and antioxidant effects of epigallocatechin-3-gallate. Asia Pac J Clin Nutr 16 (Suppl 1): S153-S157, 2007.

30. Saeki K, Kobayashi N, Inazawa Y, Zhang H, Nishitoh H, Ichijo H, Saeki K, Isemura $M$ and Yuo A: Oxidation-triggered c-Jun N-terminal kinase (JNK) and p38 mito-gen-activated protein (MAP) kinase pathways for apoptosis in human leukaemic cells stimulated by epigallocatechin-3-gallate (EGCG): A distinct pathway from those of chemically induced and receptor-mediated apoptosis. Biochem J 368: 705-720, 2002.

31. Elbling L, Weiss RM, Teufelhofer O, Uhl M, Knasmueller S, Schulte-Hermann R, Berger W and Micksche M: Green tea extract and (-)-epigallocatechin-3-gallate, the major tea catechin, exert oxidant but lack antioxidant activities. FASEB J 19: 807-809, 2005.

32. Yang GY, Liao J, Li C, Chung J, Yurkow EJ, Ho CT and Yang CS: Effect of black and green tea polyphenols on c-jun phosphorylation and $\mathrm{H}(2) \mathrm{O}(2)$ production in transformed and non-transformed human bronchial cell lines: Possible mechanisms of cell growth inhibition and apoptosis induction. Carcinogenesis 21: 2035-2039, 2000.

33. Yang GY, Liao J, Kim K, Yurkow EJ and Yang CS: Inhibition of growth and induction of apoptosis in human cancer cell lines by tea polyphenols. Carcinogenesis 19: 611-616, 1998.

34. Koňariková K, Ježovičová M, Keresteš J, Gbelcová H, Duračková $\mathrm{Z}$ and Žitňanová I: Anticancer effect of black tea extract in human cancer cell lines. Springerplus 4: 127, 2015.

35. Feng Q, Torii Y, Uchida K, Nakamura Y, Hara Y and Osawa T: Black tea polyphenols, theaflavins, prevent cellular DNA damage by inhibiting oxidative stress and suppressing cytochrome P450 1A1 in cell cultures. J Agric Food Chem 50: 213-220, 2002

36. Wei H, Zhang X, Zhao JF, Wang ZY, Bickers D and Lebwohl M: Scavenging of hydrogen peroxide and inhibition of ultraviolet light-induced oxidative DNA damage by aqueous extracts from green and black teas. Free Radic Biol Med 26: 1427-1435, 1999.

37. Ghosh D, Dey SK and Saha C: Antagonistic effects of black tea against gamma radiation-induced oxidative damage to normal lymphocytes in comparison with cancerous K562 cells. Radiat Environ Biophys 53: 695-704, 2014.

38. Ghosh D, Pal S, Saha C, Chakrabarti AK, Datta SC and Dey SK: Black tea extract: A supplementary antioxidant in radiation induced damage to DNA and normal lymphocytes. J Environ Pathol Toxicol Oncol 31: 155-166, 2012.

39. Łuczaj W and Skrzydlewska E: Antioxidative properties of black tea. Prev Med 40: 910-918, 2005.

40. Chung JY, Huang C, Meng X, Dong Z and Yang CS: Inhibition of activator protein 1 activity and cell growth by purified green tea and black tea polyphenols in H-ras-transformed cells: structure-activity relationship and mechanisms involved. Cancer Res 59: 4610-4617, 1999. 